\title{
Research on the Transmission Path of Carbon Control, Financial Development and Technological Innovation
}

\author{
Zhao Na \\ School of Finance, Zhongnan University of Economics and Law, Wuhan, 430073, China
}

Keywords: Carbon controls; Financial development; Technological innovation; DAG analysis

\begin{abstract}
In order to study the transmission path between carbon control, financial development and technological innovation, a directed acyclic graph method for unit root test, co-integration test and causality analysis was conducted based on the panel data of 22 provinces and cities in China from 2004 to 2015. The results show that there is a long-term equilibrium co-integration between carbon regulation, financial development and technological innovation. There is a facilitating role between carbon regulation and financial development; Carbon control is the direct cause of technological innovation, that is, carbon control directly promotes technological innovation; Carbon regulation is also an indirect cause of technological innovation. Carbon regulation promotes financial development and thus enterprise technological innovation.
\end{abstract}

\section{Introduction}

In recent years, the world has become more and more concerned about environmental issues and carbon dioxide emissions. At present, China's economic development has reached a certain stage, and the reform and opening up has promoted the substantial economic growth. With this, China's environmental pollution has gradually become prominent, especially the carbon dioxide emission has increased sharply along with the economic growth. How to coordinate economic, social and environmental development? China has been taking a very positive attitude towards carbon emission reduction. In 2004, China issued the medium - and long-term plan for energy conservation, and in 2005, the law on renewable energy utilization was passed. In recent years, China's energy consumption per unit of GDP fell by 5\% in 2016, exceeding the annual target of reducing by more than 3.4\%. China's total energy consumption was 4.36 billion tons of standard coal, up by about $1.4 \%$ year on year, lower than the annual growth target of about $3 \%$ in the 13th five-year plan period. China has reduced its carbon dioxide emissions by 4.1 billion tons in the past decade while its economy has grown, xie zhenhua, China's special representative on climate change, said at the launch of China's annual report on climate change policies and actions 2017. Indeed, it has achieved the coordination between climate action and economic and social development and achieved winwin results. China has actively participated in the global climate governance process, especially in the process of the conclusion, signing and entry into force of the Paris agreement. In addressing climate change, China has taken the lead of the international community in balancing the two interests, integrating domestic sustainable development with climate action.

As for the effect of carbon control on technological innovation, it can be achieved through tax system, energy price adjustment and other means. The increase of energy price can directly affect the use of energy intensity. In order to reduce costs, enterprises make full use of energy to improve technology, thus promoting their technological innovation. Lichtenbrg (1986) [1] pointed out that if the energy price increases, enterprises can constantly increase the investment in research and development, and the output rate can still be improved, thus it can be concluded that energy price increases can promote technological innovation. Popp (2002) [2] adopted 1970-1994 U.S. patent, energy price and technological innovation data, and the results showed that energy price can significantly promote technological innovation of energy efficiency. Yao xilong et al. (2014) [3] conducted an empirical study on energy factor price, environmental regulation intensity and green innovation efficiency by means of impulse response and variance decomposition, and concluded that there is a long-term co-integration relationship between energy factor price, environmental 
regulation intensity and green innovation efficiency. Both energy factor price and environmental regulation intensity have positive effects on green innovation efficiency. Longfei, qi huibo et al. (2016) [4] simulated and analyzed the technological innovation mechanism of enterprises under different carbon tax scenarios, and concluded that enterprises only made technological innovation after the carbon tax rate rose to 128 yuan/ton to reduce carbon emissions. Luo chuanjian and liu zhangsheng (2017) [5] considered that the price of ladder price had a significant impact on both the number of patents and the technical center by taking the household ladder price as the entry point and adopting the virtual variable, double difference and other methods.

\section{Research methods and data}

\subsection{Research methods}

The panel data is different from the common single time series unit root test. The panel unit root test needs to consider the AR (1) process:

$$
\mathrm{y}_{\mathrm{it}}=\alpha_{\mathrm{i}} \mathrm{y}_{\mathrm{it}-1}+\beta_{\mathrm{i}} \mathrm{X}_{\mathrm{it}}+\mu_{\mathrm{it}}
$$

In formula (1), $\mathrm{I}=1,2,3 \ldots, \mathrm{N} . \mathrm{T}=1,2, \ldots \mathrm{Ti}$; Among them, the sample number $\mathrm{N}$ for individual section, Ti for cross section sample observation periods, Xit as exogenous variables of the model, contains the individual section fixed effect and time trend effect, mu it as random error of the model, independent identically distributed, alpha I for vector autoregressive coefficients, when | alpha I $\mid<1$, has been testing the yi as a stationary series, dangdang $\mid$ alpha $\mid \mathrm{I}=1$, has been testing the yi for nonstationary sequence.

The test is divided into two types: one type includes the LLC test, which has the same unit root test; The other is IPS, adf-fisher and pp-fisher tests, which do not have the same unit root test.

In order to test the long-term equilibrium relationship between carbon control, financial development and technological innovation, this paper adopts several test methods to carry out cointegration test for time series of various variables, including LLC test, Breitung test, adf-fisher test and pp-fisher test. The $\mathrm{P}$ value of the test statistic is:

$$
\mathrm{P}=-\sum_{i=1}^{N} \log \left(p_{i}\right) \rightarrow \chi^{2}(2 N)
$$

$\mathrm{Pi}$ is the $\mathrm{P}$ value of the $\mathrm{i}$-th cross-section cointegration test, and $\mathrm{N}$ is the number of cross-section samples. If the statistical value of $\mathrm{P}$ is greater than the critical value, there is a co-integration relationship, and vice versa.

Before making a directed acyclic graph analysis of carbon control, financial development and technological innovation, it is necessary to establish an auto-regression model (VAR) of panel data vector, and then obtain the correlation coefficient between the three. The vector autoregressive model is expressed as:

$$
Y_{t}=A_{1} Y_{t-1}+A_{2} Y_{t-2}+\ldots+A_{i} Y_{t-p}+\varepsilon_{t}, \quad(t=1,2, \ldots, T)
$$

\subsection{Index selection and data processing}

In this paper, panel data of 22 provinces and municipalities in China from 2004 to 2015 were selected. It is difficult to directly obtain the data of the implementation intensity of carbon control policies. In the existing literature, the emission of different pollutants can be used as the index to measure the environmental regulation intensity when measuring the environmental regulation intensity, that is, the larger the pollutant emission, the stronger the environmental regulation (Domazlicky, Weber,2004) [12]. According to also USES the method to measure carbon control strength, is used to measure the carbon dioxide (CO2) emissions, the greater the emissions of carbon dioxide, carbon control dynamics, the more carbon dioxide emissions is estimated by calculating the coal, coke, crude oil, fuel oil, gasoline, kerosene, diesel oil, natural gas, eight kinds of energy consumption, to their own carbon emissions coefficient for the weighted sum of the 
weights.

As the financing method in China is mainly indirect financing, measuring the scale of financial development and using the indicator financial institution loan balance/gross domestic product (GDP) to measure, the larger the loan balance of financial institutions, the larger the scale of financial development. Technical innovation indicators include the number of patent authorizations (PA) and r\&d intensity (RD), and the consumer price index (CPI) is used to offset the impact of price. Data from China financial statistical yearbook from 2000 to 2015, the China energy statistical yearbook and Wind database, such as Tibet, chongqing, guizhou has deficiencies in several provinces and cities some years data, in order to guarantee the reliability of data and scientific, this paper to eliminate processing of the data of several provinces, in order to eliminate the influence of different variance, respectively for $\mathrm{PA}, \mathrm{RD}$, respectively take the natural logarithm of CO2 and become $\ln \mathrm{PA}$, $\operatorname{lnRD}$ and $\operatorname{lnCO} 2$.

\section{Empirical Analysis}

In order to avoid the problem of pseudo-regression, we first test the stationarity of relevant data. The test method is to perform the panel unit root test on the relevant data, and the results are shown in table 1 . According to the results shown in table $1, \mathrm{FS}, \operatorname{lnRD}, \ln \mathrm{PA}$ and $\operatorname{lnCO} 2$ cannot reject the null hypothesis of "existence of unit root" in LLC test, IPS test, adf-fisher test, and pp-fisher test, that is, existence of unit root. It can be seen from the results that the original sequences are all nonstationary. However, after the first order difference of the variables, all variables rejected the null hypothesis at a significant level of 5\%, indicating that the sequences of FS, $\operatorname{lnRD}, \ln \mathrm{PA}$ and $\operatorname{lnCO} 2$ were first order integral.

Table 1 Unit root test of panel data

\begin{tabular}{|c|c|c|c|c|c|c|c|c|c|}
\hline \multirow{2}{*}{\multicolumn{2}{|c|}{ Test Method }} & \multicolumn{4}{|c|}{ Original Value } & \multicolumn{4}{|c|}{ First-order Difference Value } \\
\hline & & FS & $\operatorname{lnRD}$ & $\ln \mathrm{PA}$ & $\operatorname{lnCO} 2$ & FS & $\operatorname{lnRD}$ & $\ln \mathrm{PA}$ & $\operatorname{lnCO} 2$ \\
\hline \multirow{2}{*}{\multicolumn{2}{|c|}{$\begin{array}{c}\text { LLC test } \\
\text { IPS test }\end{array}$}} & $1.59^{* *}$ & $3.15^{* *}$ & $7.62 * *$ & $2.52 * *$ & $-12.71 * *$ & $-17.8^{* *}$ & $-11.28 * *$ & $-10.25^{* *}$ \\
\hline & & $4.7^{* *}$ & $3.35^{* *}$ & $13.29 * *$ & $3.49 * *$ & $-6.55^{* *}$ & $-13.53 * *$ & $-7.77 * *$ & $-9.45^{* *}$ \\
\hline \multicolumn{2}{|c|}{ ADF-Fisher test } & $34.93 * *$ & $48.55^{* *}$ & $4.33 * *$ & $61.35^{* *}$ & $137.75 * *$ & $253.64 * *$ & $167.4^{* *}$ & $194.8^{* *}$ \\
\hline \multirow{2}{*}{\multicolumn{2}{|c|}{$\begin{array}{c}\text { PP-Fisher test } \\
\text { test model }\end{array}$}} & $29.49 * *$ & $49.88^{* *}$ & $7.97 * *$ & $84.18^{* *}$ & $230.16 * *$ & $326.02 * *$ & $204.87 * *$ & $306.44^{* *}$ \\
\hline & & $\mathrm{I} \& \mathrm{~T}$ & $\mathrm{I} \& \mathrm{~T}$ & I & $\mathrm{I} \& \mathrm{~T}$ & $\mathrm{I} \& \mathrm{~T}$ & I\&T & $\mathrm{I}$ & $\mathrm{I} \& \mathrm{~T}$ \\
\hline \multirow{2}{*}{$\begin{array}{c}\text { Test } \\
\text { variables }\end{array}$} & \multirow{2}{*}{\multicolumn{2}{|c|}{ The null hypothesis }} & \multicolumn{2}{|c|}{$\begin{array}{c}\text { FisherStatistical } \\
\text { quantity }\end{array}$} & \multirow{2}{*}{$\mathrm{P}$} & \multicolumn{2}{|c|}{ FisherStatistical quantity } & \multirow{2}{*}{\multicolumn{2}{|c|}{$\mathrm{P}$}} \\
\hline & & & (from tr & ce test) & & $\begin{array}{l}\text { (from th } \\
\text { feature }\end{array}$ & $\begin{array}{l}\text { maximum } \\
\text { oot test) }\end{array}$ & & \\
\hline \multirow[t]{2}{*}{$\begin{array}{l}\text { FS and } \\
\operatorname{lnRD}\end{array}$} & \multicolumn{2}{|c|}{ there is no } & \multicolumn{2}{|c|}{223.9} & 0.0000 & \multicolumn{2}{|c|}{152.7} & \multicolumn{2}{|r|}{0.0000} \\
\hline & \multicolumn{2}{|c|}{ Up to 1} & \multicolumn{2}{|c|}{197.5} & 0.0000 & \multicolumn{2}{|c|}{197.5} & \multicolumn{2}{|r|}{0.0000} \\
\hline \multirow[t]{2}{*}{$\begin{array}{l}\text { FS and } \\
\ln P A\end{array}$} & \multicolumn{2}{|c|}{$\begin{array}{l}\text { There is no co- } \\
\text { integration }\end{array}$} & \multicolumn{2}{|c|}{211.9} & 0.0000 & \multicolumn{2}{|c|}{143.1} & \multicolumn{2}{|r|}{0.0000} \\
\hline & \multicolumn{2}{|c|}{ Up to 1} & \multicolumn{2}{|c|}{195.2} & 0.0000 & \multicolumn{2}{|c|}{195.2} & \multicolumn{2}{|r|}{0.0000} \\
\hline \multirow[t]{2}{*}{$\begin{array}{l}\text { FS and } \\
\operatorname{lnCO} 2\end{array}$} & \multicolumn{2}{|c|}{$\begin{array}{l}\text { There is no co- } \\
\text { integration }\end{array}$} & \multicolumn{2}{|c|}{369.1} & 0.0000 & \multicolumn{2}{|c|}{236.3} & & 0.0000 \\
\hline & Up to 1 & & & & 0.0000 & & & & 0.0000 \\
\hline $\begin{array}{c}\ln R D \text { and } \\
\operatorname{lnCO} 2\end{array}$ & $\begin{array}{l}\text { There is no } \\
\text { integration }\end{array}$ & & & & 0.0000 & & & & 0.0000 \\
\hline & Up to 1 & & & & 0.0000 & & & & 0.0000 \\
\hline $\begin{array}{c}\ln P A \text { and } \\
\operatorname{lnCO} 2\end{array}$ & $\begin{array}{l}\text { There is no } \\
\text { integration }\end{array}$ & & & & 0.0000 & & & & 0.0000 \\
\hline & Up to 1 & & & & 0.0000 & & & & 0.0000 \\
\hline $\begin{array}{c}\operatorname{lnRD} \text { and } \\
\operatorname{lnPA}\end{array}$ & $\begin{array}{l}\text { There is no } \\
\text { integration }\end{array}$ & & & & 0.0000 & & & & 0.0000 \\
\hline & & & & & 0.0000 & & & & 0.0000 \\
\hline
\end{tabular}




\section{Conclusion}

The data of this paper is derived from 12 years' data of 22 provinces and cities from 2004 to 2015, including China statistical yearbook, China financial statistical yearbook, China energy statistical yearbook and Wind database. The purpose of this paper is to study the internal correlation between carbon control, financial development and technological innovation. In this paper, in order to do the panel unit root tests, panel cointegration test, VAR analysis and causal analysis (DAG), regulation, financial development on carbon and the transmission path analysis of technology innovation, now have the following main conclusions: (1) by the results of unit root test of panel data for carbon controls, financial development and technology innovation two long-term stable equilibrium relationship between the two. (2) carbon control is introduced to the development of financial development mainly through the policy effect, and carbon emission reduction constraint can also guide the development direction of financial institutions through the government making some policies, which has a positive effect on financial development, and is significant at the $1 \%$ statistical level, indicating that carbon emission reduction constraint has a promoting effect on financial development. (3) carbon control can lead to technological innovation development through indirect effects. Carbon control first promotes the development of financial institutions, and then promotes technological innovation of enterprises through the development of financial institutions, all of which are statistically significant at the level of 1\%. Financial development has a significant positive effect on $R \& D$ investment, and $R \& D$ investment has a significant positive effect on scientific research results. (4) the direct effect of carbon control also leads to technological innovation of enterprises. The degree of carbon emission reduction constraint has a positive effect on technological innovation, and is significant at the $1 \%$ statistical level, indicating that carbon emission reduction binding has a promoting effect on technological innovation of enterprises. In conclusion, the empirical results show that carbon control policy directly promotes technological innovation in various ways. Carbon control intensity has a direct positive effect on financial development, and financial development has a direct positive effect on technological innovation. Carbon control policies directly contribute to technological innovation in various ways.

The empirical results of the study not only help to theoretically understand the internal influencing mechanism between carbon regulation, financial development and technological innovation, but also help relevant government departments to formulate and implement relevant policies and measures. First of all, the intensity of carbon control to play a direct role in promoting financial development, the future direction for China's financial institutions also play a role in guiding, results demonstrate the validity of the carbon control policies of our government to get a good play, can continue by promoting the development of financial institutions, financial institutions to give full play to the government plays a important role in the mediation, the financial institutions to build Bridges between the government and enterprises, the government for financial institutions to create a good environment for development, promote the financial development, also want to strengthen the supervision of financial institutions and maintain the stability of financial markets, so as to better promote economic development; Financial development plays an promoting role in technology innovation, the enterprise technological innovation needs a large number of longterm financing, financial institutions to provide financing support and direction guide, show that in various areas of our country should actively promote the development of financial institutions, in order to boost the development of low-carbon economy, bank credit need for environmental protection projects, strengthen the role of green credit, through the support of financial institutions, to promote industrial institutions accelerating ascend, foreign investment project is in line with the requirements of environmental protection to be the key evaluation, actively introduce foreign environmental technology projects, never play a role of technology spillover of foreign investment; Carbon controls to play a direct role in promoting technological innovation, the strengthening of carbon control can increase the cost of enterprise, enterprise in order to increase profits, must increase investment in technology innovation, suggests that provinces in our country can implement low-carbon economy development goal, actively formulate relevant policies to reduce emissions, such as energy price controls, the implementation of a carbon tax, strengthen the enforcement of 
carbon regulation.

Creating a competitive atmosphere and other indirect ways to promote other members to improve efficiency

\section{References}

[1] Teece D J. A dynamic capabilities-based entrepreneurial theory of the multinational enterprise[J]. Journal of International Business Studies, 2014, 45(1): 8-37.

[2] Gafiyatullina A Z, Nikonova T V, Vagin S G, et al. Organization of controlling the intellectual potential of company personnel[J]. Review of European Studies, 2015, 7(4): 13.

[3] Kozlenkova I V, Samaha S A, Palmatier R W. Resource-based theory in marketing[J]. Journal of the Academy of Marketing Science, 2014, 42(1): 1-21.

[4] Masalimova A R, Nigmatov Z G. Structural-functional model for corporate training of specialists in carrying out mentoring[J]. Review of European Studies, 2015, 7(4): 39.

[5] Lackéus M, Williams Middleton K. Venture creation programs: bridging entrepreneurship education and technology transfer[J]. Education+ Training, 2015, 57(1): 48-73.

[6] Azevedo C L B, Iacob M E, Almeida J P A, et al. Modeling resources and capabilities in enterprise architecture: a well-founded ontology-based proposal for ArchiMate[J]. Information Systems, 2015, 54: 235-262.

[7] Damiani M, Pompei F, Ricci A. Family Firms and Labor Productivity: The Role of Enterprise-Level Bargaining in the Italian Economy[J]. Journal of Small Business Management, 2016. 